\title{
Design-based approaches to engage youth in the transition to sustainability
}

\author{
Najla Mouchrek ${ }^{1}$ \\ ${ }^{1}$ Virginia Tech, Individualized Interdisciplinary PhD, Human Centered Design, Blacksburg, VA, USA
}

\begin{abstract}
This research aims to study how the integration of design thinking and participatory design applied to education experiences can promote engagement in sustainability and pro-environmental behaviour among young students. The potential of Design to support the culture of sustainability among youth, bridging the value-action gap in pro-environmental behaviour and developing sustainable competencies is investigated. The research uses a qualitative multi-method approach. This paper summarizes the findings of the exploratory phase consisting in literature review, context analysis, and ethnographic observation and pilot application of Participatory Design activities in undergraduate courses. Preliminary findings show that design-based participatory approaches integrated in educational settings offer excellent opportunities to positive intervention to both engage youth in sustainability and support their positive development.
\end{abstract}

Keywords. Design for Sustainability, Youth, Engagement, Culture, Participatory Design.

\section{Introduction}

In the current socio-economic-environmental context, it is increasingly important to invest in fostering a culture of sustainability among youth, developing processes and interaction strategies to create 'contexts for change'. As Autio and Heinonen (2004, p.150) emphasize: "young people need to reflect on the future of the world and what is the meaning of 'good life' for them. They are the future consumers, producers and agents of change".

This research aims to study how the integration of Design thinking and Participatory Design applied to education experiences can promote engagement in sustainability and pro-environmental behaviour among young students.

\section{Background}

\subsection{Culture of sustainability among youth}

The concept of sustainability encompasses several dimensions: social, cultural, ecological, environmental, territorial, economic and political. In the present study, the focus is on socio-cultural and educational dimensions. The term 'culture of sustainability' refers to the necessity and centrality of a cultural shift in how individuals and society address economic, social and environmental issues (DUXBURY \& GILLETTE 2007).

\footnotetext{
${ }^{a}$ Corresponding author: najlammouchrek@gmail.com
}

The transition towards sustainability constitutes a process of social learning, which should redirect the lifestyles and the concepts of wellness aiming at the quality of life as a whole (MANZINI 2008).

Duxbury and Gillette highlight the importance of engaging youth in sustainability discussions:

"involving young people in educational programs on cultural, social, environmental, and economic forms of sustainability can help provide them with a more optimistic and sustainable outlook on the future" (DUXBURY \& GILLETTE 2007, p. 11).

Young people are the core of our present and the key actors in the future. It is especially regarding the new generations that the changes towards healthier, integrated and sustainable lifestyles are fundamental.

\subsubsection{The value-action gap in pro-environmental behaviour}

The process of behaviour change toward sustainability and social engagement is complex, does not correspond to a linear model in which the ecological knowledge would lead to awareness and this directly to action. We observe a value-action gap in these processes, with barriers to behavior change (ROIZMAN 2001; BLAKE 1999; KOLLMUSS \& AGYEMAN 2002).

Overcome this gap would lead to a fundamental shift in behavior towards sustainability. Although some 
authors attribute the value-action gap to the lack of appropriate information (BLAKE 1999), other authors affirm that the gap will not be overcome simply by increasing information (BARR \& GILG 2002; SAMMER \& WÜSTENHAGEN 2006; ROIZMAN 2001; MOUCHREK 2014; LEITNER et al 2011; AUTIO \& HEINONEN 2004). There are several other barriers, which might be:

- personal, structural and social (JACKSON 2005; BLAKE 1999)

- individual, responsibility, practical (BLAKE 1999).

There are several theorethical models aimed to explain the value-action gap in proenvironmental behaviour and propose strategies to bridge this gap. We would like to highlight the Kollmuss \& Agyeman's (2002) model, which lists the following aspects :

- Demographic factors

- External factors (institutional, economic, social and cultural)

- Internal factors (motivation, environmental knowledge and awareness, emotional involvement, locus of control, responsibility and priorities

Especially regarding young people, it is important to consider factors such as social norms, motivation and emotional involvement. In this phase, social and cultural context can act as barrier or facilitator for sustainable behaviour (ROIZMAN 2001).

Young people live contradictions between expressed sustainable values and concrete actions. It is often observed that they are aware of sustainable values and practices, but this is not necessarily evident in their attitudes and consumer behaviour (LEITNER et al 2011, AUTIO \& HEINONEN 2004). This does not necessarily indicate disinterest or lack of responsibility on their part, but the overall picture is so complex and the notions of citizenship and active social participation are so diluted that it might be difficult for young people to imagine themselves playing an active role in the process of transformation towards sustainable ways of living.

The young person lives a period of great inner revolution, facing fundamental questions about personal identity, interpersonal relations and definition of a life pathway. Youth live sustainability related to concrete situations in real life, such as choices, decisions, academic and professional direction. A promising strategy would consist in promoting empowerment and autonomy while developing competencies related to sustainability. Empowerment is fundamental in the developing citizenship, because it enables young people to be agents of change and active subjects in problemsolving, developing autonomy and self-esteem.

\subsubsection{Competencies to develop and desired outcomes}

In the search of ways to bridge the aforementioned value-action gap and promote youth engagement in the transition to sustainability, it is fundamental to promote the development of a set of competencies, in order to enable an active and reflective participation among youth (CENTER FOR ECOLITERACY 2006; MOUCHREK 2014, BARTH et al., 2007, FINN et al. 2013):

- Critical thinking, reflection and awareness

- Creative and foresighted thinking

- Ability to apply ethical principles

- Empathy and transcultural understanding

- Self-knowledge and self-regulation

- Autonomy

- Problem-solving and decision making in complex scenarios

- Participatory skills and ability for taking action

Engaging youth in community issues and efforts toward sustainability has important implications both to positive youth development as well as for the community development (BROWNE et al 2011). There are many evidences that highlight the need to provide new frameworks and foster the development of new skills in order to create a culture of sustainability.

\subsection{Design as a catalyst for change}

The practice of Design is changing and there is a growing focus on Design as a process, with designers increasingly being consulted to develop strategies to deal effectively with change and complexity (CASSIM 2013). The field offers a range of potentialities and interfaces for innovative action in the context of the transition towards a sustainable culture and lifestyle.

Several authors point out that Design can be a powerful catalyst in this subject, proving to be an effective methodology of intervention (MANZINI 2008). Designers can contribute towards sustainability in many directions: proposing plural solutions and designing new scenarios (KRUCKEN 2008); establishing conditions for a creative context; developing tools, equipment and infrastructure to support promising practices (MALAGUTI 2009); using their knowledge and specific tools to facilitate convergence towards shared ideas and potential solutions (MANZINI 2008).

Innovative perspectives considering Design as a way of knowing and inquiring allow for substantial progress in understanding and tackling complex issues: "thinking like a designer can transform the way you approach the world when imagining and creating new solutions for the future" (RIVERDALE COUNTRY SCHOOL \& IDEO, 2011, p. 3).

Design shows its potential as a methodology for intervention through a dynamic set of skills, cognitive processes, methodologies and structural aspects (BANERJEE 2008; OWEN 2005; d.SCHOOL 2010):

- Applied and creative knowledge field.

- Human-centered focus (human values and empathy).

- Combination of various cognitive processes.

- Iterative method of working (developing concepts on multiple fronts in real context). 
- Systemic vision.

- Synthesis and ability to visualize and communicate possible futures.

- Affinity for team work and radical collaboration (culture of creativity and shared vision between different disciplines).

At this point, a connection with the skills required to involve young people in the transition to sustainability (as described in the previous section) is clearly observed, reinforcing the idea that Design offers an excellent opportunity for development in this field.

\section{Method}

The nature of this research is qualitative; it uses a multimethod approach, using concepts and tools from Design research to combine knowledge from many disciplines. Yee and Bremner (2011) defend the idea that the 'methodological bricolage' is the very paradigm of Design research, due to the indeterminate nature of the field and it is also evidence that Design is moving beyond its disciplinary framework, combining, adapting and creating new connections between disciplines.

The preliminary phase of the research was developed at Master's degree level (2012-2014), being considered as an initial approach to the subject, intended to map the context and understand the general characteristics of the issue. The target audience was young people between 14-24 years, especially Design students. The methodology involved exploratory survey (literature review, interviews with experts, survey and cases studies); and experimental application of innovative interaction strategies on 2 different educational settings, based on processes of co-creation in Design.

The current phase is in-progress, being developed in the context of a $\mathrm{PhD}$ degree, and aimed to advance the research, developing a detailed study on applying Design thinking and Participatory Design in order to establish novel connections and possibilities of intervention on the youth's engagement with the transition to sustainability. The audience is college students between 18-25 years, and the focus is on the development of empowerment as a key aspect of youth's engagement with sustainability in the transition to adulthood.

This paper summarizes the findings of the exploratory phase at the PhD level, which consisted in: (a) literature review (involving works in diverse disciplinary fields); (b) analysis of context in the light of the theoretical works both in youth development (cognitive and social development aspects) and youth contemporary culture; and (c) ethnographic observation and pilot application of participatory design activities in three undergraduate interdisciplinary courses. The following phases will involve a pilot data collection with survey and semistructured interviews; and further development of codesign sessions with students.

\section{Findings}

Preliminary findings point that Design may be considered as a promising activity to engage youth in sustainability and support their development, since the application of participatory approaches based on cocreation in Design and innovative applications of Design in educational settings offer excellent opportunities for positive intervention in the field.

\subsection{Participatory Design with youth}

Coming from a democratic tradition, Participatory Design processes are well-suited to support innovative approaches to social change and emerge as promising strategies to promote engagement in sustainability among youth.

The origins of Participatory Design (PD) date back to movements toward democratization at work in Scandinavian countries in the 1970s. Participatory approaches in Design are guided by the general idea of involving the end-users as full participants in activities leading to design products, services, activities and systems. Typical features are: collective construction of knowledge, mutual learning, prototyping, and iteration.

When well-managed, Participatory Design practices produce mutual learning and transformative outcomes for all participants. The most interesting participatory processes are those that avoid hierarchical positioning and configure participants as agents with voice, resources, and authorship (WRIGHT \& MCCARTHY, 2015). Co-design activities encourage systems thinking; enable people to be active participants and suppliers of solutions; reveal new ways and possibilities of doing things; and strengthen the sense of trust and mutual growth (FUAD-LUKE 2010).

Considering potential strategies for engaging youth in sustainability, it is noted that:

- Participatory Design processes can provide spaces for experimentation, inviting youth to reflect and enact choices in a non-serious, playful environment.

- From the perspective of development, Participatory Design processes with young people can offer opportunities for peer interaction, equal participation with adults, exploration of diverse identities, and elaboration of possible futures.

- Participatory processes can improve youth's ability to understand and contribute to (trans)forming their life contexts, exercising skills for protagonism and positive intervention (youth as co-creators of public space).

- Open, participatory environments are ideal to enable young people to exercise their critical and creative thinking skills and help them reflect on values and choices and constitute their own principles. Placing Participatory Design activities as opportunities for experimentation contributes to the integral development of young people. 
Co-creation activities are suited to develop the culture of sustainability among youth, since they contribute to: developing critical thinking to analyze complex problems and find innovative solutions; providing fields of experimentation for students to create solutions from their own resources and motivations; offering a range of tools and forms of intervention they learn collaboratively how to select and apply; developing concrete and actionoriented projects; and establishing a dynamic system, in which feedback and confirmation stimulate new cycles of project and applied action (MOUCHREK 2014).

\subsection{Design as strategy for teaching and learning}

One possible area for intervention lies in the interconnection of Design and Education. It is observed a great congruency between the thinking and making processes in which design professionals engage and the demands today's students will likely face as adults (DAVIS et al 1997).

The current scenario highlights the importance of developing participatory skills of different natures, such as technical, critical, creative and ethical (KAFAI \& PEPPLER 2011). Formative processes that include experiences in Design could answer to those needs, promoting opportunities to develop these skills, learning to how to (FONTOURA 2001; DAVIS et al., 1997): use tools and resources to materialize ideas; use strategies such as prototyping, modelling, drawing, planning; work in teams and develop social interaction abilities. Students' involvement in the Design process can also develop important abilities of "reflection-in-action" (SCHÖN 1987).

Considering potential strategies for engaging youth in sustainability, it is noted that:

- The integration of designerly ways of thinking in the classroom opens opportunity to develop structured reflection and critical consciousness, both precursors of an intentional and active engagement with sustainability;

- If the Design competencies are combined with a discussion focused on sustainability, the impact in the learning process is expanded, allowing students to articulate their values and discuss potential strategies for application;

- Introducing tools and strategies from designerly ways of doing in the classroom allows students to learn practical skills that would be useful in their engagement in sustainability and social change in the community (such as: graphic design, multimidia, verbal and visual expression, team work etc).

As a subject of investigation and a mode of inquiry that makes direct connections with problem solving in daily life, the application of Design thinking and practices in learning experiences offers a genuine promise for preparing students to be thinking, informed citizens who can shape progress in the 21 st century (DAVIS et al. 1997).

\section{Final considerations}

Social responsibility, improvement of quality of life and the role of Design in a sustainable and positive future are important considerations to human-centered designers. Therefore, the relationship between youth, engagement in sustainability and its implications for the future should be considered a relevant theme of study, research and development in the field. It matters to investigate the potential processes of learning, socialization and innovation that are able to support and encourage sustainable choices and engagement with social change among young people - and the possible strategies for design-based interventions.

\section{Acknowledgments}

The author would like to thank Dr. Lia Krucken and Dr. Mark Benson for the academic support during diverse stages of the research and Dr. Jill Sible (Office of Undergraduate Academic Affairs at Virginia Tech) for the funding support.

\section{References}

AUTIO, M.; HEINONEN, V. To consume or not to consume? Young people's environmentalism in the affluent Finnish society. Young, v. 12, n. 2, p. 137-153, 2004.

BANERJEE, B. Designer as Agent of Change. A Vision for Catalyzing Rapid Change. Changing the Change Conference, Torino, Italy, 2008.

BARR, S.; GILG, A. Environmental communication and the cultural politics of environmental citizenship. Environment and Planning A. 30: 14451460, 1998. doi:10.1068/a301445.

BLAKE, J. Overcoming the 'value-action gap' in environmental policy: tensions between national policy and local experience, Local Environment, 4(3), pp. 257278, 1999. doi:10.1080/13549839908725599.

BROWNE, L., GARST, B., \& BIALESCHKI, M. Engaging Youth in Environmental Sustainability: Impact of the Camp 2 Grow Program. Journal Of Park And Recreation Administration, 29(3), 2011. Retrieved from http://js.sagamorepub.com/jpra/article/view/2256.

CASSIM, F. Hands on, hearts on, minds on: design thinking within an education context. International Journal of Art \& Design education, 32(2), 190-202, 2013.

CENTER FOR ECOLITERACY. Education for Sustainabiity - Competences, 2006. Available at: http://www.ecoliteracy.org/education/competences.html. 
d. SCHOOL. Bootcamp Bootleg. Institute of Design at Stanford University, 2010. Available at http://dschool.typepad.com/files/bootcampbootleg2010v 2slim-1.pdf.

DAVIS, M., HAWLEY, P., MCMULLAN, B. \& SPILKA, G.. Design as a Catalyst for Learning. Alexandria: Association for Supervision and Curriculum Development, 1997.

DUXBURY, N., \& GILLETTE, E. Culture as a key dimension of sustainability: Exploring concepts, themes, and models. Centre of Expertise on Culture and Communities, 2007.

FINN, T., CENNAMO, K., BAUM, L. \& NEWBILL, P. Creative Collaboration: Trans-disciplinary Methods to Enhance Critical and Creative Thinking. In Society for Information Technology \& Teacher education International Conference (Vol. 2012, pp. 2781-2785), 2012.

FONTOURA, A. M. EdaDe: a educação de crianças e jovens através do Design. Tese (Doutorado em Engenharia de Produção). Universidade Federal de Santa Catarina. Florianópolis, Brasil, 2002.

FUAD-LUKE, A. Co-creation loop. Interview to Gina Lovett (online), 2010. Available at: http://marciodupont.blogspot.com/2010/02/entrevistacom-o-alastair-fuad-luke.html.

JACKSON, T. Motivating Sustainable Consumption: A Review of Evidence on Consumer Behaviour and Behavioural Change. A report to the Sustainable Development Research Network. London: SDRN, 2005.

KAFAI, Y. \& PEPPLER, K. Youth, Technology, and DIY: Developing Participatory Competencies in Creative Media Production. In V. L. Gadsden, S. Wortham, and R. Lukose (Eds.), Youth Cultures, Language and Literacy. Review of Research in Education, 35(1), pp. 89-119, 2011.

KOLLMUSS, A. \& AGYEMAN, J. Mind the Gap: Why do people act environmentally and what are the barriers to pro-environmental behavior?, Environmental Education Research, 8:3, 239-260, 2002. doi: 10.1080/13504620220145401.

KRUCKEN, L. Competências para o Design na sociedade contemporânea. In: Cadernos de Estudos Avançados em Design Sustentabilidade Transversalidade. 1 ed. Belo Horizonte: Santa Clara, v. $1,2008$.

LEITNER, M.; CHRISTANELL, A.; BERTSCH, C.; BRUNNER, K. My life - my style - my future. Nachhaltige Lebensstile und jugendliche Lebenswirklichkeiten. Final report. Vienna: Institute for Sustainable Development, 2011.

MALAGUTI, C.S.. Design e valores materializados cultura, ética e sustentabilidade. In: Cadernos de Estudos Avançados em Design Sustentabilidade I. 1 ed. Barbacena: EdUEMG, v.1, 2009.
MANZINI, E. Design para a inovação social $e$ sustentabilidade: comunidades criativas organizações colaborativas e novas redes projetuais. Rio de Janeiro: Cadernos do Grupo de Altos Estudos, v. 1, 2008.

MOUCHREK, N.. Estratégias e competências de Design para promover a cultura de sustentabilidade entre jovens. Dissertação (Mestrado). Escola de Design, Programa de Pós-Graduação em Design da Universidade do Estado de Minas Gerais, Belo Horizonte, Brasil, 2014.

OWEN, C. L. Design Thinking. What It Is. Why It Is Different. Where It Has New Value. Life and Design in the Future Conference, Keynote address. South Korea, 2005.

RIVERDALE COUNTRY SCHOOL \& IDEO. Design Thinking for Educators. New York, 2011. Available at http://www.designthinkingforeducators.com.

ROIZMAN, L. G.. Sustentabilidade e ética ecológica: valores, atitudes e a formação ambiental de educadores. Tese de Doutorado. Universidade de São Paulo, 2001.

SAMMER, K.; WÜSTENHAGEN R. The Influence Of Eco-Labelling On Consumer Behaviour - Results Of A Discrete Choice Analysis For Washing Machines. Business Strategy and the Environment Special Issue: Sustainability Marketing. 15 (2): 185-199, 2006.

SCHÖN, D. A. Educating the reflective practitioner: Toward a new design for teaching and learning in the professions. San Francisco, CA, 1987.

WRIGHT, P., \& MCCARTHY, J. The politics and aesthetics of participatory HCI. Interactions, 22(6), 2631, 2015.

YEE, J. \& BREMNER, C. Methodological bricolage: What does it tell us about design? In: Doctoral Design education Conference, 23-25 May 2011, Hong Kong Polytechnic, Hong Kong, 2011 